\title{
Strategy for A Sustained Quality Delivery Mode of ODL Programmes for Massive Enrollments and E-learning: The Case for Zimbabwe Open University
}

\author{
Gabriel Kabanda ${ }^{1}$
}

${ }^{1}$ Zimbabwe Open University, Zimbabwe

Correspondence: Gabriel Kabanda, Zimbabwe Open University, Zimbabwe. E-mail: gabrielkabanda@gmail.com

Received: May 9, 2014

doi:10.5430/ijhe.v3n3p154
Accepted: June 3, 2014

Online Published: August 22, 2014

URL: http://dx.doi.org/10.5430/ijhe.v3n3p154

\begin{abstract}
The market dynamics in distance education has precipitated phenomenal growth opportunities in enrollments and e-learning. The purpose of the paper was to develop a strategy for sustained quality delivery mode of distance education progammes that precipitate massive enrollments and e-learning in an open and distance learning (ODL) institution using Zimbabwe Open University (ZOU) as a case study. There is an increase in public accountability for higher education which compels institutions to demonstrate quality within the programmes and processes, including those provided online. The strategy for massive enrollments and e-learning is developed and this includes a mobile strategy and mobile web framework. How the landscape of quality assurance has been changed by the emergence of MOOCs is discussed. The methodology used is qualitative and focus groups were used as research designs in the case study of Zimbabwe Open University (ZOU). Triangulation and peer review was used to test the validity of the data. Strategic directions were developed to inform the new key result areas, goals, objectives, strategies and priorities for the university for the period 2015-2020.
\end{abstract}

Keywords: Quality assurance, ODL, Mobile learning, E-learning, MOOCs, Strategy, ICTs, Online

\section{Introduction}

Open and distance learning (ODL) has experienced a phenomenal growth worldwide (Mupa et al, 2012), and its success depends on quality assurance. Developments in the distance education space for contact, dual mode and dedicated open and distance learning (ODL) institutions show growth opportunities in enrollments and a huge appetite for e-learning programmes of various shapes and sizes often offered through online, blended form or face-to-face. Distance education policy at various institutions is going through an evolutionary process with a desire to introduce and sustain high quality programmes. On the contrary, the market dynamics are precipitating massive enrollments in distance education programmes with a view to increase access. E-learning is being introduced by various institutions with no uniform approach to integration into the curricula. It appears more attractive and possibly profitable to offer programmes through distance education, hence the proliferation of a variety of ODL formats such as parallel programmes, block-release programmes, residential schools, etc. A research university is challenged on how to effectively offer distance education under the new dispensation. However, examinations have to remain face to face in all courses for all programmes.

The Zimbabwe Open University (ZOU) is a State University, which was established on 1st March 1999 as an open and distance learning (ODL) university. The ZOU provides ODL throughout the ten (10) Regional Centres in each Province countrywide, as shown on the diagram below on Figure 1, and one Virtual Region for coordination and management of the e-learning platform accessible from anywhere in the world. 


\section{ZOU Regional Centres}

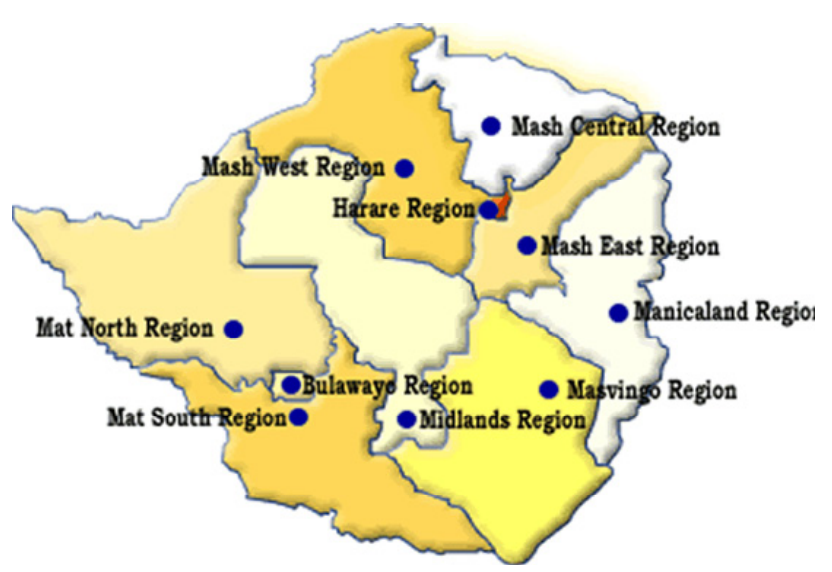

Figure 1. The Regional Centres of Zimbabwe Open University

The ZOU, whose vision is to become a world-class open and distance learning university, offers pre-service and in-service ODL certificate, diploma and degree programmes. At the moment the university offers 43 programmes ranging from undergraduate to Doctor of Philosophy (DPhil/PhD) level. As an ODL university, ZOU is accessible to students from remote districts in all provinces of the country and reduces urban bias, provides easy and convenient accessibility to higher education, and there are no emigration challenges to far countries. The student enrolment levels for ZOU between 2005 to 2013 sadly went down mainly due to the economic downturn experienced by the country from 2007 to 2009 . The student registrations per semester are now beginning to pick up as the economy stablilises, as shown on Figure 2 below.

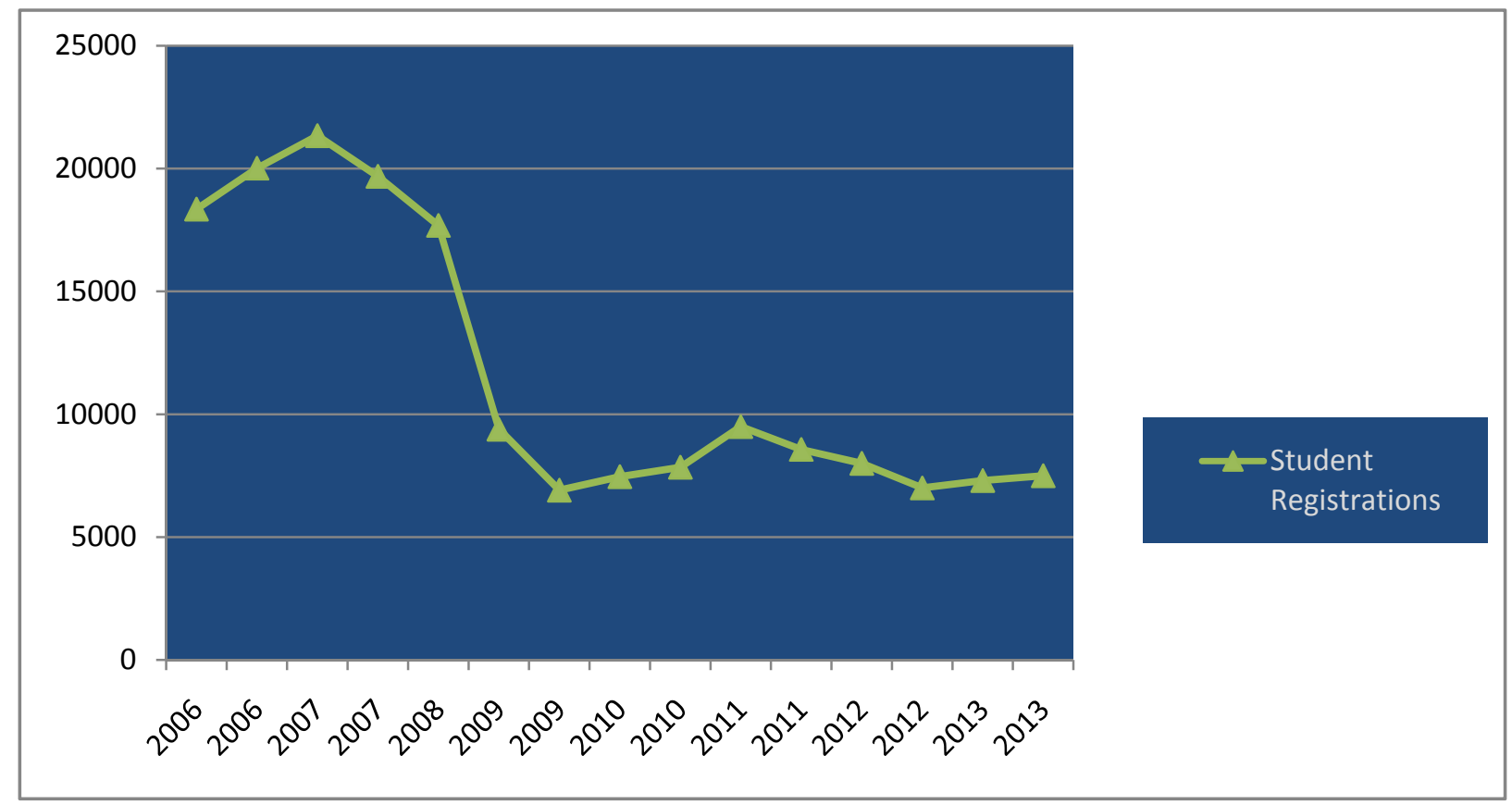

Figure 2. ZOU Student Registrations per Semester (2005-2013)

Zimbabwe faced an economic down-turn between 2007 and 2009 during which a multi-currency economy was introduced in 2008. The economic implication was a relatively stable economic environment characterised by a tightening in economic activity, lack of liquidity, salary structure for civil servants that lagged behind the poverty datum line and a general fall in the standards of living. This debilitating environment negatively affected the 
potential base for the ZOU students, who are largely employed civil servants. The deployment affected the enrolment trend of the university, which started to fall, thus negatively affecting some institutional fundamentals, like revenue collection and budgetary allocations. The debt account of the institution from students who failed to honour their financial obligations increased, accompanied by, but not related to, the falling government support. ZOU students are workers who are directly affected by the macro-economic situation, as most of them are parents who have to pay school fees for their children first before considering theirs.

According to the Reserve Bank of Zimbabwe (2014), the Zimbabwean economy is currently facing the following major challenges:

1. A severe and persistent liquidity crunch which has made it very difficult for local productive sectors to access sufficient credit to oil the wheels of the economy;

2. Lack of competitiveness of locally produced goods due to high costs of production resulting in the huge importation of finished goods, hence the widening current account deficit;

3. Infrastructure bottlenecks especially around key economic enablers such as energy, transport, communication. These bottlenecks have eroded of viability and competitiveness of local producers in key economic sectors; and

4. Inadequate and often erratic service delivery from parastatals and local authorities.

ZOU students are generally over borrowed with loans and affordability of studies being seriously challenged. Notwithstanding the deceleration in deposit growth, the loans to deposit ratio increased from $37.33 \%$ in June 2009 to $78.29 \%$ as at $31^{\text {st }}$ December 2013 as shown in the graph below. The predominance of short-term deposits has constrained the banking sector's potential to provide effective financial intermediation to productive sectors of the economy. The tenor of lending has remained confined to the short-term at a time when the productive sectors require long-term funding for re-tooling.

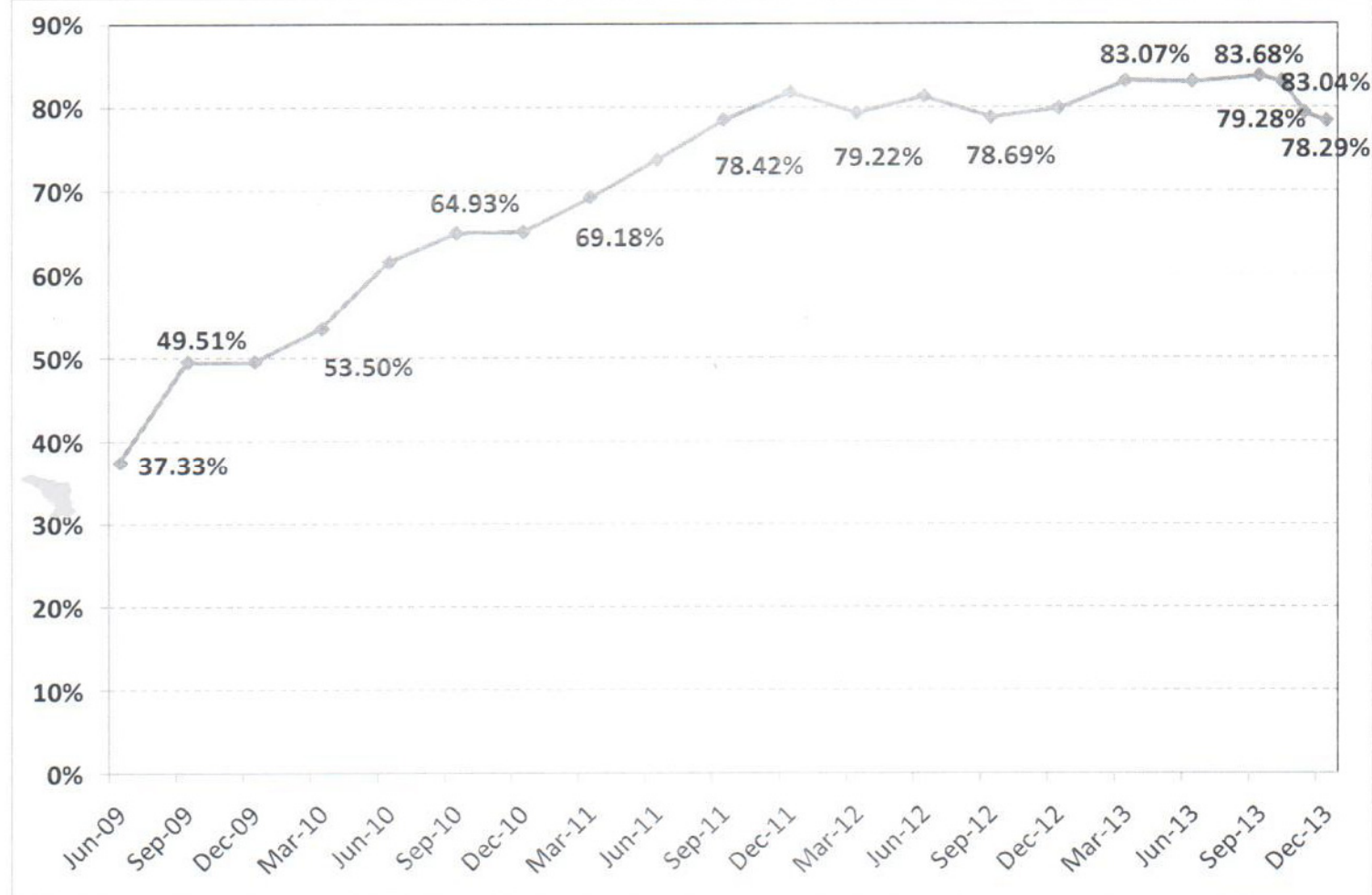

Figure 3. Loans to Deposits Ratio June 2009 to December 2013 (RBZ, 2014)

There is an increase in public accountability for higher education which compels institutions to demonstrate quality within the programmes and processes, including those provided online. Besides the link between quality of education and economic performance, the growing concern on quality has been triggered mainly by cultural relevance, impact 
on population, poverty and HIV/AIDS, contribution to the development process in rural areas, life-long learning and achievement of MDG goals (Kabanda G., 2012). The main problem, evidenced by the contributing factors to the enrolment levels of ZOU shown on Figure 2, has symptoms observed in the following areas:

- Quality learning materials

- Verification of studentship and assessment methods

- Poor learner support

- Incompetent facilitators

- Poor management of workload of lecturers or academics

- Facilitation and tutorials often compromised

- Mushrooming of illegal Centres for tutoring with compromised quality and potential damage to branding of the institutions

- E-Tutoring services not yet successful

- The younger generation is loosing interest in attending tutorials but prefers the use of e-tutoring services

- Introduction of practicals in some practical scientific programmes faces numerous challenges

- The role of E-learning in research supervision is not yet clear.

\section{Statement of the Problem}

The market dynamics in distance education has precipitated phenomenal growth opportunities in enrollments and e-learning. However, the effectiveness of the delivery mode appears to be compromised with respect to quality, assessments, management and governance of the programmes. The case study for Zimbabwe Open University examines why the enrollment levels went down due to the economic situation prevailing in Zimbabwe and are now slowly picking up whilst 15 conventional universities have experienced increased enrollments through dual mode. Quality is about the degree or grade of excellence. A strategy for a sustained quality delivery mode of ODL programmes for massive enrollments and e-learning is, therefore, required under the circumstances.

\section{Purpose or Aim}

To develop a strategy for sustained quality delivery mode of distance education progammes under the new dispensation of increasing enrollments and huge appetite for e-learning in ODL institutions.

\section{Objectives}

The objectives of the research are to:

1. Assess the quality assurance frameworks for ODL programmes

2. Develop a gap analysis of ODL institutions

3. Evaluate the management of ODL institutions under the new dispensation

4. Develop a strategy for sustained delivery and growth of ODL programmes

5. Develop the mobile strategy and web frameworks for higher education in Africa.

\section{Research Questions}

1. What is the quality assurance framework currently in use for ODL programmes?

2. What gap needs to be addressed by ODL institutions to stimulate growth and support massive enrollments?

3. How do you manage the ODL institutions under such prevailing challenges?

4. How do you develop a sustained quality delivery mode for ODL programmes?

5. What is the most appropriate mobile strategy and mobile web framework for higher education in Zimbabwe?

\section{Rationale/ Justification}

The regulatory frameworks governing ODL programmes requires attaining a minimum set of standards that demonstrate performance and code of good practice benchmarked against international standards. The development of a sustained quality delivery mode is a sufficient and necessary condition to comply with the expectations of the regulatory frameworks and achieving a high degree of stakeholder satisfaction. Management and governance of higher education institutions offering ODL programmes has become increasingly challenging. The research will offer 
significant value adding contributions to the institutions offering ODL programmes under the new dispensation. A mobile strategy and mobile web framework is developed.

\section{Review of Related Literature}

Globalization has created increased demand for a work force with more broader skills, competences and knowledge. ODL is the key driver in human capital development adequately equipped with competences in privatization, marketization, commodification, managerialism and performativity (Mupa et al, 2012). This, naturally, results in a formidable external demand for quality assurance (QA). Quality Assurance is a systematic, structured and continuous attention to quality. The purpose of a QA system is to ensure that educational activities are of high quality and are developing toward further improvements. Globalization and market forces have an impact on QA. All the 43 programmes of ZOU are accredited by the Zimbabwe Council for Higher Education (ZIMCHE). Both accreditation and quality assurance are important in improving the quality of educational programmes and their delivery.

The University's vision and mission statements set out its aims for providing a high quality student learning experience, whilst the learning and teaching strategy sets out the objectives for the development and enhancement of the curriculum and the student learning experience. The University's Quality Assurance Framework supports these aims and objectives by specifying the responsibilities and procedures by which the standards of the academic programme and the quality of the student learning experience are managed, assured and enhanced (Kabanda G., 2012). The conceptual framework for quality dimensions in higher education, which largely informs the quality assurance policy of ZOU, is dimensioned by tangible facilities, competence of the academics, learner support mechanisms, content that meets the minimum body of knowledge in a given field, and delivery efficiency. According to Kabanda G. (2012), experience with the Zimbabwe Open University (ZOU) shows that the key elements of the Quality Assurance Framework include the following:

\section{External Reference Points with the Regulatory Authority}

2. Programme regulations and academic policies

3. Examination Boards and External Examiners

4. Senate programme approval processes

5. Programme and Module review processes

6. Collaborative programmes with Associates, Affiliates and other partners

7. Student involvement in Quality Assurance and Learner Support

8. Enhancement of the Quality Assurance Framework to ensure fitness for purpose and fitness of purpose.

Kawachi P. (2013) defined Open Educational Resource (OER) as a small self-contained unit of self-assessable teaching with a measurable learning objective, often in digital format and generally free to use. Overall OERs are not serving their original purpose for which they were designed and these have increasingly become of poor quality with little or no two-way interactivity, weak multimedia, choices, and generally bad instructional design (Kawachi P., 2010). One of the best new trends is the e-portfolio which serves as a visualization of a student's engagement and participation, and this visualization further stimulates the student's transactional presence that directly is the first step in learning. A group of students could work together collaboratively on an e-portfolio, and so future uses of e-portfolios can be wiki-based co-creation of courseware by the students themselves (Kawachi P., 2010)

Challenges to the quality of higher education in Africa include the following (Woldetensae, 2013):

$\circ$ High increase in enrollment

- Inadequate facilities and infrastructures

- Shortage of qualified staff and heavy workloads

- Outdated teaching methods, rely on lectures

$\circ$ Weakening of research and publishing activities

- Mismatch between graduate output \& employment

- Low level of quality management system and limited capacity of governance \& leadership

- Many countries are yet to establish regulatory agencies for QA and Accreditation

$\circ$ In some countries, quality monitoring and accreditation is employed only in Private HEIs 
○ Many HEIs are facing challenges that are affecting their quality - Enrolment expansion

- Problems of comparability (credit transfer)

- Many initiatives in promoting QA in Africa but they are disparate \& uncoordinated, with little collaboration among regions \& key organisations

E-learning is learning supported or enhanced through the application of Information and Communications Technology (ICT), and has become an important pillar in open and distance learning. E-learning encompasses supported learning, blended learning and to learning that is delivered entirely online. E-learning is main driven by advances in mobile technologies, demand for ubiquitous services by learning providers, and mobile operators who are promoting new applications, services and markets.

Mobile learning (m-learning) is digital mobile learning that is facilitated and enhanced by the use of digital mobile devices that can be carried and used anywhere and anytime. Mobile and ubiquitous learning concept is different from e-Learning. It is of paramount importance, therefore, to develop a reference mobile-learning architecture that is attractive to key actors encompassing adaptive human interfaces, context-awareness tools, collaborative learning environment, and integration of mobile media delivery and learning content management systems. Successful case studies on mobile learning assessed by Traxler J. (2009), include the following approaches:

1. Technology-driven mobile learning where specific technological innovation is deployed in an academic setting to demonstrate technical feasibility and pedagogic possibility;

2. Miniature but portable e-learning that uses mobile, wireless, and handheld technologies that re-enact approaches and solutions already used in conventional e-learning;

3. Connected classroom learning that support collaborative learning and may include interactive whiteboards;

4. Informal, personalized, situated mobile learning enhanced with additional functionality to deliver educational experiences;

5. Mobile training/ performance support to improve the productivity and efficiency of mobile workers; and

6. Remote/rural/development mobile learning that addresses environmental and infrastructural challenges of delivering and supporting education over w wider geographic dispersion.

M-learning standards are purposed to:

- Ensure resources are compatible with baseline delivery contexts and hardware platforms;

- Exploit the capabilities of specific devices to maximise quality and usability, and provide alternative formats for a range of devices; and

- $\quad$ Organize the architecture according to client platforms, mobile content development, mobile content delivery, and mobile content support.

There is a need to take advantage of rapid developments in ICT and rich sources of content, and invest in high quality learning, to remain globally competitive against the challenge from international and private providers. Online learning can be used to enhance student choice and meet learners' expectations; realignment of training and development to support academics to play a leading role in online provision; and the development and sharing of open educational resources to enhance efficiency and quality. Massive open online educational courses (MOOCs) are only a segment of the distance education and online course delivery landscape that has existed for years. Educational technology, such as MOOCs, requires fundamental items to be setup and implemented successfully and these are power, Internet connectivity and bandwidth, quality teacher training, respect and better pay for teachers, and the sustainability of implementations. MOOCs have been criticized for their low completion rates due to challenges of financial sustainability and accessibility to them by those who have limited or no access to reliable power, Internet connections, ICTs, and educational support (Wright C.R., 2014).

The quality assurance of post-traditional higher education has become more complicated due to the openness and flexibility dimensions. Openness is an increasing factor in mainstream education, with value being attached to concepts such as open content, open data, and open educational resources (OER), along with notions of transparency and easy access to data and information (Butcher N. and Wilson-Strydom M., 2013). The emergence of massive open online courses (MOOCs) has changed the landscape of quality assurance. The term MOOCs originated in 2008 from a web course based on an extensive and diverse set of content, contributed by a variety of experts, educators, and instructors, and aggregated into a central repository. All course materials and the course itself were open source and free, with the option of a paying a fee for those wishing to obtain university credit. However, the MOOC concept took 
a very different turn in 2012, when a number of top-notch universities offered informal learning on various topics to large global audiences using a very traditional instructional model. Students who passed the computerized tests could not obtain credit, and in most cases the study materials did not carry open licenses (Butcher N. and Wilson-Strydom M., 2013).

Existing institutional courses have often simply been translated into a web-based environment and made available to all (Butcher N. and Wilson-Strydom M., 2013). Whilst the two types of courses, often called $\boldsymbol{c M O O C s}$ and $\boldsymbol{x M O O C s}$ respectively, have some common features, they clearly differ in the learning theory and pedagogical model they employ - in particular, the ways in which social interactions happen during the courses. Furthermore, the concept of openness behind each of the formats contrasts sharply.

- cMOOCs are based on a philosophy of connectivism and networking, where students learn from educators and from each other in online course environments that are largely community constructed and driven.

- $\mathrm{xMOOCs}$ tend to follow traditional behaviourist approaches to learning and the structure of existing educational practices. They typically have traditional course structures, content, and methods, with videotaped lectures, online quizzes, and weekly assignments. Their primary innovation is scaling.

Despite their differences, MOOCs offer learning opportunities to millions of people and have the potential to reach and serve very large numbers of learners who would otherwise not have access to education. This provides learning close to zero cost, enabling students, lifelong learners, and professionals to acquire new skills and improve their knowledge and employability. The pedagogical styles of MOOCs have also diversified greatly with recent offerings having features of both cMOOCs and xMOOCs.

\section{Methodology}

The methodology used is qualitative in order to discover meaning and potential relationships. This seeks patterns and generalizations from the available data. Focus groups were used as research designs in the case study of Zimbabwe Open University (ZOU). Triangulation and peer review was used to test the validity of the data.

The case study for ZOU used focus group discussions where a total of 100 participants were split into 4 focus groups at the Strategic Plan development workshop of ZOU from $8^{\text {th }}$ to $10^{\text {th }}$ April, 2014 with a specific focus to craft the strategic direction and strategies to grow the university for the period 2015-2020. The four focus groups focused on corporate target areas/ key result areas with goals in the following items shown on Table 1 below. 
Table 1. Focus Group Discussion Areas

Group Key Result Area

Goal Areas

Growth

Strengthen ZOU Brand

Stakeholder Satisfaction

Strengthen ZOU products and services
Market Reach

Strengthen Resource Mobilisation

Strengthening financial management systems

University governance

Strengthen ZOU policies, systems and processes

Strengthen monitoring, evaluation and reporting

Home for ZOU - physical infrastructure

People empowerment and performance

Strong Public Relations programme

Research and development

Strengthening product development

ICT Infrastructure development and utilization

Total Quality Management

The key questions that were addressed by each focus group with respect to their key result area are as follows:

1. Develop a Gap Analysis of ZOU

2. Define the Objectives and Strategies to achieve the Key Result Area of your group

3. Develop an institutional score card for the University

\section{Results and Analysis}

The case study for ZOU used focus group discussions and depth interviews. A total of 100 participants were split into 4 focus groups at the Strategic Plan development workshop of ZOU from $8^{\text {th }}$ to $10^{\text {th }}$ April, 2014 with a specific focus to craft the strategic direction and strategies to grow the university for the period 2015-2020. The results of four (4) focus group discussions are summarized below on Table 2. 
Table 2. Focus Group Discussions on Gap, Objectives and Strategies

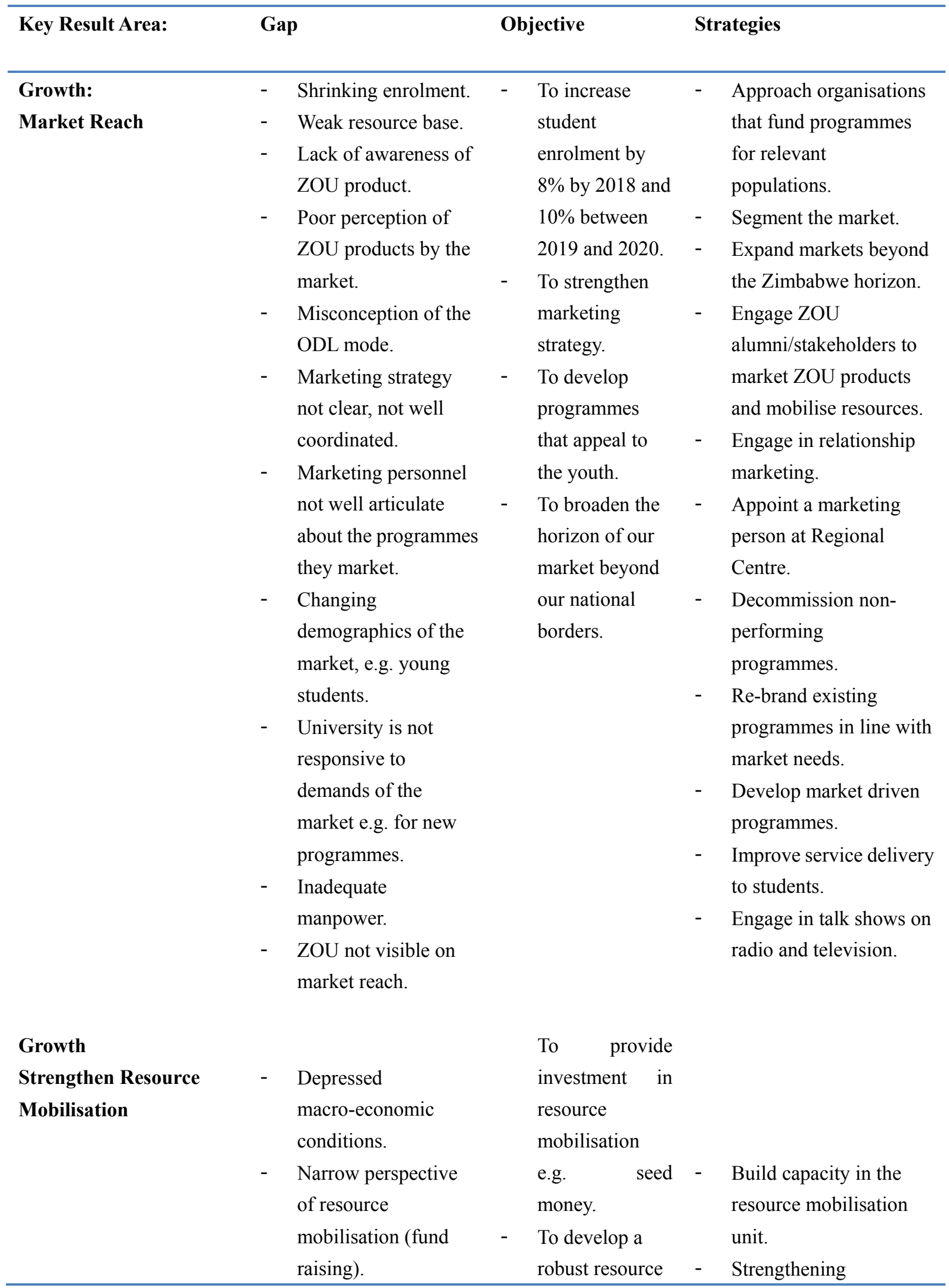




\begin{tabular}{|c|c|c|c|c|c|c|}
\hline & - & $\begin{array}{l}\text { Lack of investment in } \\
\text { resource } \\
\text { mobilisation, e.g. } \\
\text { seed money } \\
\text { Slow decision } \\
\text { making. } \\
\text { Slow to seize } \\
\text { opportunities. } \\
\text { Failure to recognise } \\
\text { opportunities. } \\
\text { Need for } \\
\text { quantification of } \\
\text { expectations. } \\
\text { Disintegration of } \\
\text { resource mobilisation } \\
\text { units. }\end{array}$ & - & $\begin{array}{l}\text { mobilisation } \\
\text { programme. } \\
\text { To empower } \\
\text { units to } \\
\text { mobilise } \\
\text { resources. }\end{array}$ & - & $\begin{array}{l}\text { partnerships. } \\
\text { Engage experts on } \\
\text { resources mobilisation. } \\
\text { Focus resource } \\
\text { mobilisation on specific } \\
\text { project at a time. } \\
\text { Integrate resource } \\
\text { mobilisation units. } \\
\text { Decentralise resource } \\
\text { mobilisation. }\end{array}$ \\
\hline $\begin{array}{l}\text { Strengthen ZOU Brand: } \\
\text { Strengthen Financial } \\
\text { Management Systems }\end{array}$ & - & $\begin{array}{l}\text { Communication gap } \\
\text { (central } \\
\text { administration and } \\
\text { units). }\end{array}$ & - & $\begin{array}{l}\text { To strengthen } \\
\text { the financial } \\
\text { capability of } \\
\text { implementing } \\
\text { staff. }\end{array}$ & - & $\begin{array}{l}\text { Training workshop in } \\
\text { financial matters. } \\
\text { Train in effective } \\
\text { communication. }\end{array}$ \\
\hline & - & $\begin{array}{l}\text { Lack of training in } \\
\text { budgeting and } \\
\text { financial } \\
\text { management. } \\
\text { Lack of awareness on } \\
\text { how ZOU gets and } \\
\text { uses financial } \\
\text { resources. } \\
\text { Lack of budgetary } \\
\text { support. } \\
\text { Lack of clear credit } \\
\text { policy. }\end{array}$ & - & $\begin{array}{l}\text { To intensity } \\
\text { income } \\
\text { generation and } \\
\text { resource } \\
\text { collection } \\
\text { procedures. }\end{array}$ & - & $\begin{array}{l}\text { Strengthen involvement } \\
\text { in business activity e.g. } \\
\text { money market } \\
\text { investment. } \\
\text { Effect efficient and } \\
\text { effective fees collection } \\
\text { e.g. Eduloan. } \\
\text { Craft credit } \\
\text { management policy }\end{array}$ \\
\hline Strengthen ZOU Brand: & & & - & $\begin{array}{l}\text { To establish } \\
\text { mechanisms for }\end{array}$ & - & Setting up Advisory \\
\hline University Governance & - & $\begin{array}{l}\text { Governance of } \\
\text { finances is too } \\
\text { centralized. } \\
\text { Lack of stakeholder } \\
\text { involvement at unit } \\
\text { level e.g. an advisory }\end{array}$ & - & $\begin{array}{l}\text { effective } \\
\text { stakeholder } \\
\text { involvement at } \\
\text { unit level. } \\
\text { To prioritise } \\
\text { University core }\end{array}$ & - & $\begin{array}{l}\text { Boards. } \\
\text { Pay service providers on } \\
\text { time. }\end{array}$ \\
\hline
\end{tabular}


board at regional

level.

- $\quad$ Lack of priorities in

financing core

business.

\section{Strengthen ZOU Brand:}

Strengthen ZOU

and processes

$\begin{array}{lll}\text { Stakeholder Satisfaction: } & -\quad & \text { No home for the } \\ & \text { National Centre. } \\ \text { Home for ZOU } & -\quad & \text { Inadequate financial } \\ & \text { resources. } \\ - & \text { Centralised control of } \\ & \text { Alumni activities. }\end{array}$
planned activities.
- $\quad$ To improve implementation of approved plans. implementing

To acquire Home for ZOU.

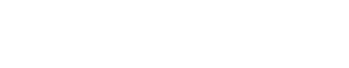

- Develop Homes for $\mathrm{ZOU}$ in regional centres: Harare, Mash West, Mash East, Mat North and Mat South.

- $\quad$ Sell Connaught House and Michael Court and use proceeds to deposit a Home for ZOU for Harare Region.

- Reduce control and management of Alumni.

- Alumni affairs to be managed by Centre for Student Management.

- Construct pre-fabricated buildings at Hatcliff site.

- $\quad$ Adopt modular building concept to construct Hatcliff .

- $\quad$ To train ZOU staff in ODL - Offer ODL training.
Stakeholder Satisfaction: - No ODL training for $\quad$ issues. - Establish a Teaching most staff since 2008. - _ and Learning centre.

People Empowerment $\quad-\quad$ No ODL trainers. $\quad-\quad$ To train ODL $\quad-\quad$ Finance staff members 


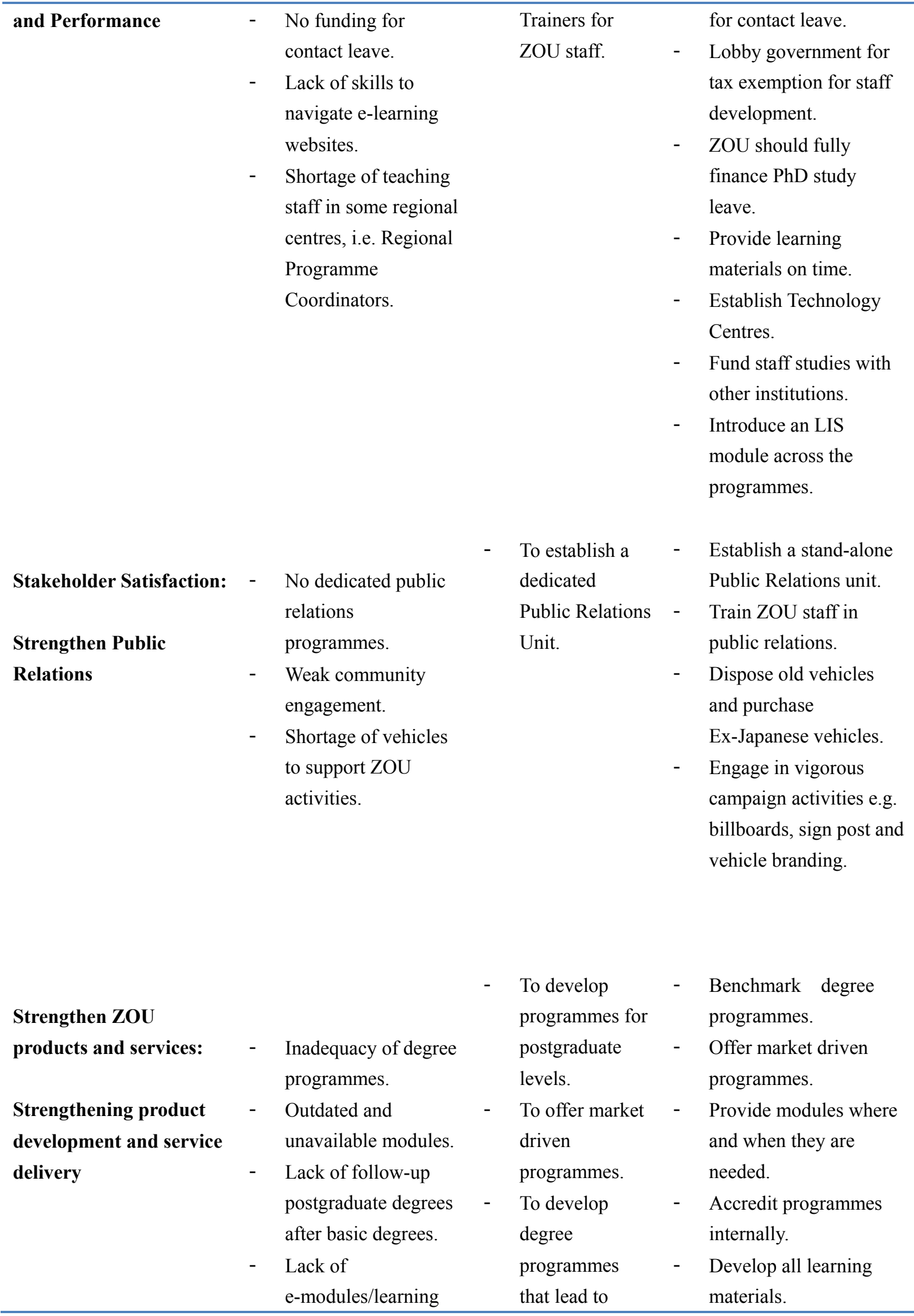




\begin{tabular}{|c|c|c|c|c|c|c|}
\hline & - & $\begin{array}{l}\text { resources. } \\
\text { Ineffective module } \\
\text { inventory } \\
\text { management. } \\
\text { Lack of resources for } \\
\text { printing modules. } \\
\text { Inaccurate } \\
\text { information given to } \\
\text { guide module } \\
\text { production. } \\
\text { Students being } \\
\text { managed by } \\
\text { "baby-sitters" } \\
\text { No feedback from } \\
\text { student advisors to } \\
\text { the faculties. } \\
\text { Lack of ODL training } \\
\text { for ZOU staff. } \\
\text { Suspension of } \\
\text { Diploma in } \\
\text { Education. } \\
\text { Unavailability of } \\
\text { locally produced } \\
\text { books. }\end{array}$ & - & $\begin{array}{l}\text { employability } \\
\text { and professional } \\
\text { mobility. } \\
\text { To update } \\
\text { modules that are } \\
\text { out of date. } \\
\text { To increase } \\
\text { availability of } \\
\text { modules. } \\
\text { To digitalise } \\
\text { learning } \\
\text { materials. } \\
\text { To avail the } \\
\text { module on time. } \\
\text { To improve } \\
\text { student: advisor } \\
\text { ratio } \\
\text { To benchmark } \\
\text { ZOU with other } \\
\text { institutions. } \\
\text { To bring to } \\
\text { finality the } \\
\text { Diploma in } \\
\text { Education issue. } \\
\text { To increase } \\
\text { textbook } \\
\text { publications. }\end{array}$ & - & $\begin{array}{l}\text { Ensure all learning } \\
\text { materials are available. } \\
\text { Launch programmes } \\
\text { whose modules are } \\
\text { available. } \\
\text { Fund MDU activities. } \\
\text { Provide effective } \\
\text { inventory management } \\
\text { system. } \\
\text { MDU to distribute } \\
\text { modules. } \\
\text { Adopt roving tutor } \\
\text { concept. } \\
\text { Establish video } \\
\text { conferencing facilities. } \\
\text { Provide faculty-based } \\
\text { student advisors. } \\
\text { Provide } \\
\text { targeted/personalised } \\
\text { student support. } \\
\text { Strengthen relationships } \\
\text { with associations and } \\
\text { organisations and } \\
\text { professional bodies. } \\
\text { Train all members of } \\
\text { staff formally, in ODL } \\
\text { practice. } \\
\text { Expedite accreditation } \\
\text { of Diploma in Education } \\
\text { to improve ZOU brand. } \\
\text { University to support } \\
\text { author in their work. }\end{array}$ \\
\hline $\begin{array}{l}\text { Total Quality } \\
\text { Management }\end{array}$ & - & $\begin{array}{l}\text { Inadequacy of degree } \\
\text { programmes. } \\
\text { Outdated and } \\
\text { unavailable modules. } \\
\text { Lack of follow-up }\end{array}$ & - & $\begin{array}{l}\text { To enhance } \\
\text { quality in } \\
\text { service delivery } \\
\text { issues. } \\
\text { To strengthen } \\
\text { ODL training of } \\
\text { ZOU full time } \\
\text { and part-time }\end{array}$ & - & $\begin{array}{l}\text { Train staff in quality } \\
\text { service delivery. } \\
\text { Offer ODL training for } \\
\text { full time and part time } \\
\text { ZOU staff. } \\
\text { Carry out research on } \\
\text { rates paid regionally and } \\
\text { internationally. }\end{array}$ \\
\hline
\end{tabular}




\begin{tabular}{|c|c|c|c|c|c|c|}
\hline & $\begin{array}{l}- \\
- \\
- \\
- \\
- \\
-\end{array}$ & $\begin{array}{l}\text { postgraduate degrees } \\
\text { after basic degrees. } \\
\text { Lack of } \\
\text { e-modules/learning } \\
\text { resources. } \\
\text { Ineffective module } \\
\text { inventory } \\
\text { management. } \\
\text { Lack of resources for } \\
\text { printing modules. } \\
\text { Inaccurate } \\
\text { information given to } \\
\text { guide module } \\
\text { production. } \\
\text { Students being } \\
\text { managed by } \\
\text { "baby-sitters". } \\
\text { No feedback from } \\
\text { student advisors to } \\
\text { the faculties. } \\
\text { Lack of ODL training } \\
\text { for ZOU staff. } \\
\text { Suspension of } \\
\text { Diploma in } \\
\text { Education. } \\
\text { Unavailability of } \\
\text { locally produced } \\
\text { books. }\end{array}$ & - & $\begin{array}{l}\text { staff } \\
\text { To enhance the } \\
\text { quality of } \\
\text { tutorials } \\
\text { through training } \\
\text { of part time and } \\
\text { full time tutors. } \\
\text { To benchmark } \\
\text { rates with other } \\
\text { Universities. }\end{array}$ & - & $\begin{array}{l}\text { Ensure timeous payment } \\
\text { of part-time tutors, } \\
\text { editors and external } \\
\text { examiners. }\end{array}$ \\
\hline $\begin{array}{l}\text { Strengthen } \mathrm{ZOU} \\
\text { products and services: } \\
\text { ICT Infrastructure } \\
\text { development and } \\
\text { utilization }\end{array}$ & $\begin{array}{l}- \\
-\end{array}$ & $\begin{array}{l}\text { Slow response to } \\
\text { student enquiries. } \\
\text { Inadequate ICT } \\
\text { facilities. }\end{array}$ & - & $\begin{array}{l}\text { To respond to } \\
\text { student } \\
\text { enquiries within } \\
48 \text { hours. } \\
\text { To provide ICT } \\
\text { facilities that } \\
\text { enable efficient } \\
\text { response to } \\
\text { student needs. } \\
\text { To provide } \\
\text { adequate library } \\
\text { facilities. }\end{array}$ & $\begin{array}{l}- \\
-\end{array}$ & $\begin{array}{l}\text { Train Call Centre staff } \\
\text { to service students } \\
\text { expeditiously. } \\
\text { Provide ICT facilities at } \\
\text { all regional centres. }\end{array}$ \\
\hline
\end{tabular}




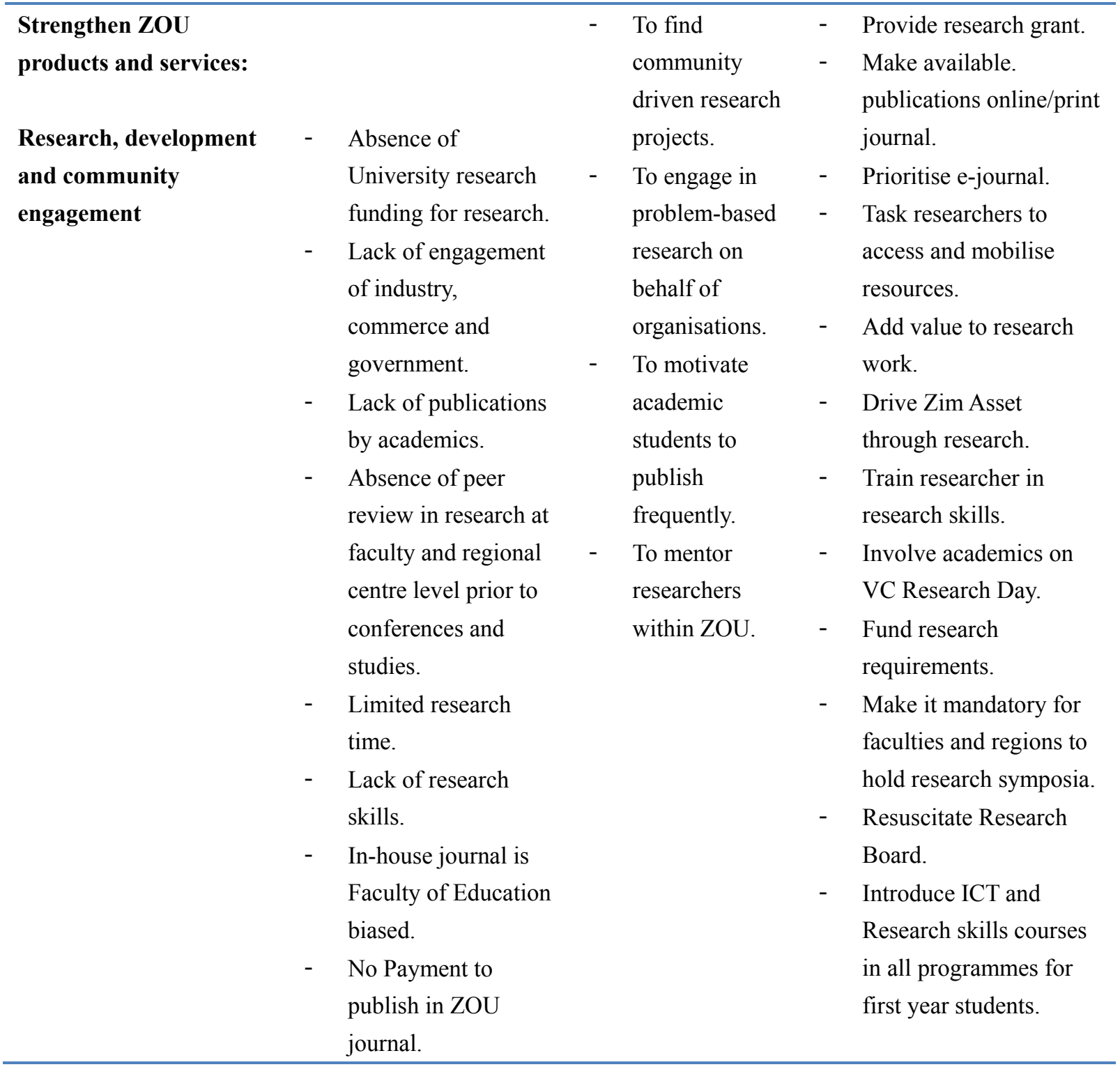

\section{Conclusion}

The market dynamics in distance education has precipitated phenomenal growth opportunities in enrollments and e-learning. The purpose of the paper was to develop a strategy for sustained quality delivery mode of distance education progammes that precipitate massive enrollments and e-learning in an open and distance learning (ODL) institution using Zimbabwe Open University (ZOU) as a case study. Management and governance of higher education institutions offering ODL programmes has become increasingly challenging. All the 43 programmes of ZOU are accredited by the Zimbabwe Council for Higher Education (ZIMCHE). The University's vision and mission statements set out its aims for providing a high quality student learning experience, whilst the learning and teaching strategy sets out the objectives for the development and enhancement of the curriculum and the student learning experience.

The strategy for massive enrollments and e-learning is developed and this includes a mobile strategy and mobile web framework. A mobile strategy and mobile web framework is recommended for adoption. E-learning is learning supported or enhanced through the application of Information and Communications Technology (ICT), and has become an important pillar in open and distance learning. E-learning encompasses supported learning, blended learning and to learning that is delivered entirely online. Mobile learning (m-learning) is digital mobile learning that is facilitated and enhanced by the use of digital mobile devices that can be carried and used anywhere and anytime. The emergence of massive open online courses (MOOCs) has changed the landscape of quality assurance. 
Strategic directions were developed to inform the new key result areas, goals, objectives, strategies and priorities for the university for the period 2015-2020. Some of the strategic directions developed include the following areas shown in Table 3 below:

Table 3. Strategic directions

\section{Key Business Function}

Strategic Directions

\section{Corporate Planning and Business Development}

\section{Administrative function}

\section{ICT strategy pillars}

Excellence ODL Model to enhance institutional performance Corporate Branding Strategy Corporate Branding Initiatives and Quick Wins for immediate implementation Corporate Innovation

New approaches to Professional Development

Centre for Professional Development (CPD) Focus Areas

Strengthening ZOU Learning and Teaching Systems in 2015-2020.

Monitoring and Evaluating Quality Factors (Learning environment, learning pathways, tutor effectiveness, feedback, activities and assessments, information presentation, social presence, background of technology).

Broadening the Bridge: Digital Immigrants and Digital Natives including online/e-learning,

Broadening the bridge: ODL Curriculum.

Broadening the e-bridge: Delivery modalities.

Increasing Access through ODL.

Resolving Funding constraints (operations and capital expenditure).

Quality dimensions compliant and TQM.

Access to and effective utilisation of ICTs.

Growth of Science and Technology programmes .

Fierce Regionalisation/Competition challenges.

Teaching and learning: improve and develop innovative ICT based teaching, learning and student assessment methods.

Management: enhance administrative effectiveness through use of integrated and computerized management systems.

Infrastructure: implement and maintain reliable and fast WANs and LANs and links to the internet.

E-literacy /Staff development: raise appropriate competencies in use of ICT by all staff. 
Library information services

Quality Assurance
Research and community development: support research and development through the provision of appropriate ICT facilities.

Growth in Collection Development.

Stakeholder satisfaction with respect to texts, databases, e-resources and library services $24 / 7$.

ICT development for KOHA, Institutional Repository, Download Center and Access Register.

Increase market reach in all provinces and in all forms of media Support mechanism for Research and Development.

World-class library facilities in all Regional Centre.

Who is ZOU?

Why Quality Management Systems?

The ZOU Quality Management System

Can TQM be achieved?

Response to strategic issues raised.

The QA Strategy.

Resources required for TQM .

\section{Financial Support}

The project took about 24 man days at a cost of US\$30,000 and was solely financed by Zimbabwe Open University.

\section{References}

Butcher N. \& Wilson-Strydom M. (2013). “A Guide to Quality in Post-Traditional Online Higher Education”, edited by Sir John Daniel and Stamenka Uvalic-Trumbic, 2013, Academic Partnerships, Creative Commons Attribution-ShareAlike $\quad 3.0 \quad$ Unported $\quad$ License. $\quad$ Retrieved from http://www.icde.org/filestore/News/GuidetoQualityinPost-TraditionalOnlineHigherEducation.pdf.

Kabanda G. (2012). "Quality materials science education for sustainable development through distance learning: the case for Nigeria and Zimbabwe", International Journal of Educational Research and Technology, Volume 3[1], March 2012, ISSN 0976-4089, IJERT-045, pages 40-51. Retrieved from www.soegra.com/ijert..htm.

Kawachi P. (2010). "e-PORTFOLIOS, CONVERGENCE, AND OPEN RESOURCES: Three New Trends in Education", International Journal on New Trends in Education and Their Implications, April, May, June 2010 Volume: 1 Issue: 1 Article: 1 ISSN 1309-6249.

Kawachi P. (2013). Quality Assurance Guidelines for Open Educational Resources: TIPS Framework, Commonwealth Educational Media Centre for Asia, New Delhi, ISBN \# 81-88770-07-8, 978-81-88770-07-6.

Koole M.L. (2009). "A model for Framing Mobile Learning”, p26-30, a book chapter in Mobile LearningTransforming the Delivery of Education: and Training, edited by Mohamed Ally, published by AU Press, Athabasca University, ISSN 1919-4382 Issues in Distance Education Series (Print), ISSN 1919-4390 Issues in Distance Education Series (Online).

Mupa P., Chiome C. \& Chabaya R.A. (2012). "Removing stumps and blocks to reach the unreached through quality assurance at the Zimbabwe Open University: a case study", Huria Journal of the Open University of Tanzania, Volume 13, August , 2012, ISSN 0856-6739, pages 1-14. 
Owlia, M S \& Aspinwall, E M (1996). "A framework for the dimensions of quality in higher education" in Quality Assurance in Education Vol 4, No 2, pp 12-20. http://dx.doi.org/10.1108/09684889610116012

Reserve Bank of Zimbabwe. (2014). The Monetary Policy Statement of Zimbabwe January, 2014. Retrieved from http://www.rbz.co.zw/pdfs/2014\%20MPS/Jan\%202014\%20MPS.pdf

Traxler J. (2009). "Current State of Mobile Learning", p12-13, a book chapter in Mobile LearningTransforming the Delivery of Education: and Training, edited by Mohamed Ally, published by AU Press, Athabasca University, ISSN 1919-4382 Issues in Distance Education Series (Print), ISSN 1919-4390 Issues in Distance Education Series (Online).

Wright C.R. (2014). "5 Key Barriers to Educational Technology Adoption in the Developing World". Retrieved from http://edutechdebate.org/2014-ict4edu-trends/5-key-barriers-to-educational-technology-adoption-in-the-develop ing-world/

Woldetensae Yohannes. (2013). "The Overall Landscape of Quality Assurance and Accreditation in Africa", African Union Commission. 